\title{
DAMPAK LUMPUR LAPINDO TERHADAP KUALITAS LINGKUNGAN PESISIR SIDOARJO DALAM RANGKA MEWUJUDKAN PEMBANGUNAN BERKELANJUTAN
}

\author{
Oleh:Suning *)
}

\begin{abstract}
Abstrak
Kabupaten Sidoarjo memiliki pantai di wilayah timur sepanjang sekitar $27 \mathrm{~km}$ yang melintasi Kecamatan Sedati, Buduran, Sidoarjo, Porong dan Jabon. Bencana lumpur Sidoarjo yang terjadi pada tahun 2006 telah berdampak luas bagi kehidupan masyarakat di pantai wilayah timur tersebut, baik dari segi sosial ekonomi masyarakat, kondisi lingkungan pesisir, kegiatan usaha maupun kegiatan transportasi.

Tujuan penelitian ini adalah untuk mengidentifikasi dan menganalisa bagaimana kondisi kualitas lingkungan yang ada di pesisir Sidoarjo akibat adanya lumpur lapindo. Metode penelitian yang digunakan adalah dengan melakukan surve data sekunder dan data primer kepada masyarakat pesisir yang menjadi responden terpilih. Analisis yang digunakan adalah analisa deskriptif dan analisa uji kualitas air dan tanah yang berdampak pada potensi hasil perikanan.

Hasil penelitian menunjukkan bahwa ada pengaruh yang signifikan terhadap kondisi sosial secara psikologis dan kondisi ekonomi secara umum. Secara sosial dan ekonomi, saat ini pemerintah dan pihak perusahaan sudah memberikan solusi dalam hal ini adalah ganti rugi. Namun kebijakan tersebut masih bersifat sepihak artinya antar korban masih terjadi ketimpangan atas biaya ganti rugi yang diberikan oleh pemerintah dan pihak perusahaan, sehingga masih sering terjadi demonstrasi diantara korban atas ketimpangan tersebut. Sedangkan hasil analisa kualitas lingkungan dengan uji laboratorium kualitas air dan tanah menunjukkan bahwa adanya bencana lumpur lapindo tidak berpengaruh secara signifikan terhadap kegiatan perikanan tambak, hal ini ditunjukkan dengan hasil produksi perikanan tambak dari tahun 2006 sampai 2010 mengalami kenaikan.
\end{abstract}

Kata kunci : Lumpur lapindo, pesisir, pembangunan berkelanjutan

\section{PENDAHULUAN}

Kabupaten Sidoarjo memiliki pantai di wilayah timur sepanjang sekitar $27 \mathrm{~km}$ yang melintasi Kecamatan Sedati, Buduran, Sidoarjo, Porong dan Jabon. Ketinggian di pantai timur ini antara $0-3 \mathrm{~m}$, dengan luas wilayah $293,57 \mathrm{~km}^{2}$ dan $29,99 \%$ dari luas wilayah yang ada merupakan daerah pesisir pantai dan pertambakan. Jumlah penduduk sebesar 494,751 jiwa dengan tingkat kepadatan penduduk 9,343 Jiwa/ $/ \mathrm{km}^{2}$ (Profil Kabupaten Sidoarjo, 2010).

Bencana lumpur Sidoarjo yang terjadi pada tahun 2006 telah berdampak luas bagi kehidupan sosial ekonomi masyarakat, kegiatan usaha, dan kegiatan transportasi. Persoalan sosial ekonomi tersebut sampai saat ini belum tertangani secara tuntas. Hasil kajian Tim TKKP tahun 2010 menyatakan bahwa terdapat 45 RT di sekitar kejadian kondisi permukiman tidak layak huni, terutama kondisi lingkungan di keluarahan Mindi dan Besuki. Kondisi lingkungan tersebut diantaranya berupa : bau gas metan, banyak bangunan/rumah yang retak, pencemaran air sumur, timbulnya bubble yang dapat mengeluarkan api, bahkan berpotensi untuk terjadi penurunan tanah (subsidence), dan rawan longsor. Kondisi tersebut masih sering terjadi sampai sekarang apalagi ketika musim hujan turun. Dalam rangka mengurangi dampak sosial dan lingkungan tersebut diperlukan suatu strategi kebijakan dari pemerintah, minimal rasa ketidaknyamanan atau keresahan masyarakat. Salah satu strategi yang mungkin dapat dilakukan adalah mengimplementasikan konsep pembangunan berkelanjutan, meskipun sulit dilakukan dan perlu pemahaman yang mendalam.

Prinsip pembangunan berkelanjutan kawasan pesisir adalah mengutamakan kondisi ekonomi jangka panjang, mempertimbangkan kondisilingkungan serta mempertimbangkan kondisi sosial (Sarda, R et al, 2005). Prinsip tersebut dapat dikembangkan kedalam unit-unit informasi yang mengarah kepada perencanaan kawasan pesisir secara terpadu. Bowen dan Riley (2003) melakukan penelitian dengan indikator sosial dan ekonomi untuk pengelolaan kawasan pesisir secara terpadu.

\footnotetext{
*) Dosen Perencanaan Wilayah dan Kota (PWK) Universitas PGRI Adi Buana Surabaya
} 
Hasil penelitiannya menunjukkan bahwa untuk pengelolaan kawasan pesisir, indikator sosial dan ekonomi harus dipadukan untuk perbaikan kondisi lingkungan pesisir baik lokal, regional maupun nasional agar sumber daya alam pesisir dapat terjaga potensi dan kelestariannya. Penelitian yang dilakukan oleh Fedra dan Feoli (1998) berjudul GIS technology and spatial analysis in coastal zone management menyimpulkan bahwa dalam pengelolaan kawasan pesisir secara terpadu diperlukan suatu dukungan secara menyeluruh mulai dari analisisdampak lingkungan, penilaian resiko, analisis kebijakan, zonasidan pemilihan lokasi. Dukungan tersebut dilakukan secara terbuka dan partisipatif dari masyarakat pesisir guna pengembangan dalam pengelolaan kawasan pesisir.

Penelitian ini bertujuan untuk mengidentifikasi dan menganalisa bagaimana kondisi kualitas lingkungan yang ada di pesisir Sidoarjo akibat adanya lumpur lapindo. Target dan luaran dari penelitian ini adalah teridentifikasinya kondisi kualitas lingkungan yang ada di pesisir Sidoarjo berdasarkan aspek sosial-ekonomi dan lingkungan.

\section{METODE PENELITIAN}

Desain penelitian digunakan untuk mempermudah dalam alur proses analisa (gambar 1). Sedangkan teknik analisis dan sasaran penelitian yang dilakukan dalam penelitian ini dapat dilihat pada tabel 1 . Metode penelitian yang digunakan adalah dengan melakukan surve data sekunder dan data primer kepada masyarakat pesisir yang menjadi responden terpilih. Analisis yang digunakan adalah analisa deskriptif dan analisa uji kualitas air dan tanah yang berdampak pada potensi hasil perikanan.

Tabel 1. Teknik analisis dan sasaran penelitian

\begin{tabular}{|l|l|l|}
\hline Sasaran Penelitian & Teknik & Output \\
\hline $\begin{array}{l}\text { Mengidentifikasi } \\
\text { dampak lumpur } \\
\text { lapindo terhadap } \\
\text { kualitas lingkungan } \\
\text { pesisir }\end{array}$ & Analisis deskriptif & $\begin{array}{l}\text { Teridentifikasinya } \\
\text { dampak lumpur lapindo } \\
\text { terhadap kualitas } \\
\text { lingkungan pesisir }\end{array}$ \\
\hline $\begin{array}{l}\text { Mengukur kualitas air } \\
\text { dan tanah yang } \\
\text { dijadikan sample }\end{array}$ & Uji Laboratorium & $\begin{array}{l}\text { Terukurnya kualitas air } \\
\text { dan tanah sebagai } \\
\text { sample kualitas } \\
\text { lingkungan y yang } \\
\text { berpengaruh terhadap } \\
\text { hasil perikanan dan } \\
\text { tambak di pesisir } \\
\text { Sidoarjo }\end{array}$ \\
\hline
\end{tabular}

Sumber: Penulis, 2012 


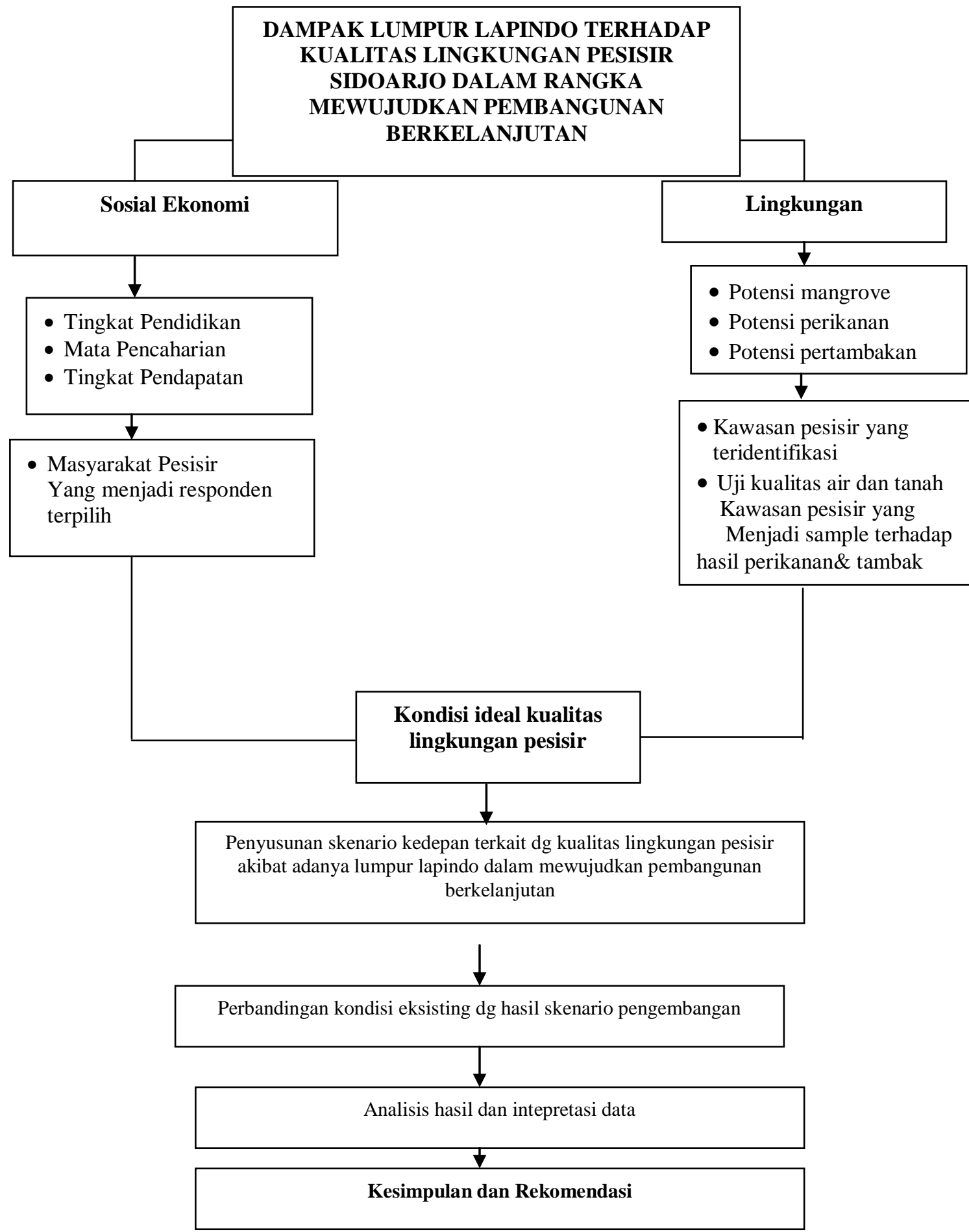

Gambar 1. Desain Penelitian

\section{HASIL DAN PEMBAHASAN}

\section{Analisa Dampak Ekonomi dan Sosial Adanya Lumpur Lapindo}

\section{a. Dampak Ekonomi}

Desa/ kelurahan yang paling dekat dengan tanggul dan belum termasuk dalam peta terdampak adalah Desa Ketapang, Pamotan,
Gemposari,KalitengahGlagaharum, Besuki timur, Keboguyang, Sentul, Penatarsewu, Plumbon dan Kalisampurno. Menempati 276 RT, jumlah rumah tangga di 13 desa/ kelurahan $13.496 \mathrm{KK}$ atau sekitar 51.571 jiwa. Mata pencaharian utama penduduk adalah petani, petambak dan sebagian diantaranya pedagang, pegawai, jasa dll. Secara umum dampak ekonomi yang 
diakibatkan oleh adanya lumpur lapindo adalah:

\section{a.1) Dampak Terhadap Sumber Penghidupan}

\begin{abstract}
Berdasarkan hasil survei saat ini yang dirasakan paling meresahkan
\end{abstract} adalah dampak ekonomi karena kegiatan pertanian terganggu. Misalkan untuk Desa Sentul, pertanian terganggu karena kesulitan air (harus mengambil dari Desa Penatarsewu) sehingga biaya mahal atau mengandalkan tadah hujan. Pencemaran air juga menyebabkan bibit mati. Selain itu kesulitan membawa hasil panen karena Pasar Kedungbendo sudah tidak ada dan harus dibawa ke Pasar Porong dengan biaya transportasi lebih besar. Pembuangan air lumpur melalui Kali Alo (apabila pihak BPLS membuka dam aliran air di sungai tersebut) sangat mengganggu pertanian di Desa Penatarsewu karena air tercemar. Pernah terjadi dalam satu tahun tidak panen sama sekali. Jika dam di buka warna air sungai langsung berubah menjadi hitam sehingga pengairan sawah dan tambak tercemar yang mengakibatkan panen pertanian dan tambak sangat menurun. Gagal panen yang diajukan tidak pernah mendapat tanggapan, baik dari Lapindo maupun pemerintah. Selain pertanian, perkebunan juga terganggu karena banyak pohon mangga yang mati dan sayur tidak tumbuh. Sebagian besar mata pencaharian penduduk petani dan petambak mengakibatkan hasil dari panennya rugi.

Di wilayah Desa Keboguyang, hasil pertanian merosot sampai dibawah $50 \%$ dari yang sebelumnya. Di desa ini sekitar $30 \%$ sawah (dari $120 \mathrm{Ha}$ ) yang terkena dampak lumpur mengalami puso, bibit tidak tumbuh. Disamping itu semenjak adanya air pembuangan lumpur melalui sungai yang ada di desa dan membanjiri persawahan warga maka terjadi penurunan hasil tanam bahkan tidak sedikit yang gagal panen. Pedagang (khususnya pedagang ikan) juga mengalami kemunduran karena produksi ikannya terganggu dan bahkan hasil tambak berkurang sampai $50 \%$ lebih. Sementara itu warga di Desa Plumbon mayoritas petani dan petambak, sehingga area persawahan jauh lebih luas dari area pemukiman penduduk. Semenjak adanya lumpur pendapatan warga banyak mengalami penurunan karena sawah dan tambak warga sering terbanjiri oleh air yang dialirkan melalui sungai yang ada di desa dan sungai tersebut akan meluap bila musim hujan dan luapannya membanjiri area persawahan.

Mata pencaharian penduduk Desa Besuki sebagian besar adalah petani, sekarang pengairan sawah juga tidak berfungsi karena air lumpur masuk ke sawah sehingga hasil dari panen sangat merosot. Demikian juga Desa Glagaharum, karena irigasi untuk pertanian tertutup oleh tanggul sehingga sawah tidak bisa di aliri air oleh sebab itu sekarang hanya mengandalkan sawah tadah hujan. Saat ini lahan hanya bisa ditanami tanaman pertanian dengan jenis tertentu misal kacang tanah dan padi, bahkan ada juga lahan pertanian yang sudah tidak bisa dipakai lagi karena sudah jadi tanggul. Oleh karena itu pendapatan penduduk sangat menurun karena mata pencaharian penduduk Desa Glagaharum sebagian besar adalah petani. Sedangkan Kelurahan Gedang sebenarnya di aliri oleh sungai kecil yang dulu masih berfungsi untuk pengairan sawah, tetapi sejak ada bencana lumpur air sungai tidak ada airnya. Mata pencaharian penduduk sebagian besar adalah peternak jangkrik terutama di RT 10 karena bau dari lumpur menyebabkan panen jangkriknya berkurang. Setelah ada kejadian Lumpur ini, berdasarkan hasil survey pekerjaan penduduk pada umumnya adalah sebagai wiraswasta (termasuk berdagang/ meracang) dan pegawai swasta. Khususnya warga yang mempunyai usaha di wilayah desanya (wiraswasta, pedagang), mereka dihinggapi rasa khawatir karena merasa usahanya saat ini mulai tidak aman. Kekhawatiran ini diantaranya rasa takut kehilangan pelanggan dan pihak-pihak lain (koneksi, supplier, dll) yang terhubung dengan usaha ekonomi warga. Bahkan sejak ada luapan lumpur ini, konsumen sudah mulai berkurang karena sebagian merupakan warga dari desa-desa yang sudah tenggelam. Sementara itu untuk para pengrajin tas di Kecamatan Tanggulangin juga merasakan dampak terjadi lumpur ini, karena akses jalan yang tersendat, 
usaha ekonomi mereka ikut mengalami penurunan omzet.

\section{a.2) Peningkatan Pengeluaran Rumah Tangga}

Kesulitan transportasi (karena sekarang angkot sudah tidak mau masuk desa) menyebabkan biaya hidup makin tinggi. Sebagai contoh, anakanak sekolah yang dulunya naik angkot sekarang harus pakai antar jemput atau harus punya kendaraan sendiri. Selain itu, ongkos angkutan umum pada waktu dulu sangat murah, sebagai contoh, $R p$ 1000,- sudah sampai di Pasar Porong. Sementara bagi para pekerja, selain biaya transportasi yang meningkat akibat terbatasnya akses jalan, juga memaksa mereka untuk berangkat lebih awal, selain supaya tidak terjebak kemacetan juga karena jarak tempuh saat ini menjadi lebih jauh. Hal ini tentu saja berimbas pada membengkaknya pengeluaran untuk bahan bakar kendaraan.

Kenaikan biaya hidup yang dialami oleh Desa Penatarsewu disebabkan karena tercemarnya sumur sehingga warga harus membeli air sendiri karena permohonan untuk mendapatkan tandon air belum juga dipenuhi oleh Lapindo maupun BPLS. Untuk kepentingan mandi dan cuci masih memanfaatkan air sumur sedangkan untuk minum beli air dari prigen dan isi ulang gallon padahal sebelumnya untuk minum warga juga memanfaatkan air sumur.

\section{b. Dampak Sosial}

\section{b.1) Keresahan Masyarakat karena penurunan kondisi lingkungan}

Keresahan masyarakat dirasakan oleh hampir semua warga desa. Diantara 13 desa yang disurvei Desa Mindi memiliki keresahan yang paling tinggi. Desa Mindimerupakan desa yang paling dekat dengan tanggul namun desa tersebut tidak masuk dalam peta terdampak kecuali 3 RT (RT 10, 13 dan 15), sedangkan $18 \mathrm{RT}$ lainnya belum jelas statusnya. Keresahan warga Mindi yang berlarut-larut mengakibatkan gangguan psikis karena belum ada kejelasan akan statusnya. Gangguan psikis tersebut mengakibatkan warga
Mindi sangat sensitif (emosional). Hal ini mengakibatkan pihak perangkat tidak mudah dalam mengambil sebuah keputusan, sehingga untuk permasalahan lumpur sidoarjo ini ditangani oleh sebuah forum yang ada didesa Mindi (FORKOM). Keresahan masyarakat terutama disebabkan oleh kondisi lingkungan rumah tinggal yang makin buruk dan tidak nyaman. Gangguan pernafasan dan bau menyengat dialami oleh hampir semua desa walaupun desa tersebut berlokasi agak jauh dari lokasi semburan seperti Desa Plumbon yang relatif agak jauh dari tanggul.

Penyebab keresahan berikutnya adalah banjir seperti yang dirasakan oleh desa Keboguyang, Plumbon, Besuki dan Kalisampurno. Banjir dirasa meningkat setelah adanya luapan lumpur. Di Desa Keboguyang air pembuangan dari lumpur dialirkan melalui sungai yang ada di desa sehingga waktu turun hujan maka desa tersebut pasti menjadi langganan banjir. Sedangkan di desa Kalisampurno banjir disebabkan karena pembangunan jalan tol. Ketidaknyamanan yang lain yang cukup meresahkan adalah banyaknya rumah yang mengalami kerusakan. Desa/ Kelurahan yang mengalami kerusakan rumah paling parah adalah Desa Besuki Timur dan Mindi. Bangunan rumah yang retak mengakibatkan warga sangat khawatir apabila rumah yang ditinggalinya roboh. Sedangkan untuk rumah di Desa Glagaharum, sebagian sudah mulai retak karena pergeseran kontur tanah dan tembok juga rusak. Seperti halnya warga di desa lainnya, sebenarnya warga sangat khawatir apabila rumah yang ditinggalinya roboh tetapi karena tidak ada biaya lagi untuk pindah menjadikan warga menjadi pasrah. Di RT 1 sampai 5 banyak rumah yang kosong karena sudah tidak ditinggali lagi dan bahkan ada yang sudah di bongkar karena sudah ada ganti rugi dari pemerintah walaupun masih dicicil. Adapun di Desa Pamotan, juga sudah terjadi pergeseran kontur tanah yang mengakibatkan dinding dan lantai rumah menjadi retak-retak. Kondisi paling parah terjadi pada $5 \mathrm{RT}(7,8,12$, 13 14) dan bahkan terjadi semburan air baru (terjadi sekitar Agustus 2010, di 
rumah Bp Sudarmanto, RT 7 dan $\mathrm{H}$. Jamin RT 8) yang mengakibatkan rumah sudah tidak dapat dihuni lagi. Oleh BPLS, semburan air bercampur gas tersebut dialirkan melalui pipa supaya tidak meluber.

Masyarakat juga mengalami problem transportasi karena jalan sekarang jauh lebih padat dibanding dulu. Hal ini berakibat pengeluaran untuk transportasi juga meningkat karena akses tercepat untuk menuju jalan besar Porong sudah tertutup tanggul sehingga harus melawati jalan lain. Kondisi infrastruktur di Desa Besukiterutama jalan desa agak rusak karena sering tergenang karena aliran dari lumpur. Apabila hujan jalan desa akan banjir dan airnya sulit untuk surut karena aliran selokan rusak akibat lumpur. Sedangkan jalan desa di Desa Glagaharum sebagian ada yang rusak terutama RT 6, RT 8 dan RT 18 karena dekat dengan tanggul. Kesehatan warga di semua desa juga terganggu setiap hari terutama bau yang tidak sedap yang keluar dari lumpur, yang mengakibatkan pernafasan menjadi sesak bahkan sampai mual-mual. Pada waktu awal kejadian lumpur ini, pemerintah yang diwakili Dinas Kesehatan Kabupaten Sidoarjo sering melakukan pemeriksaan kesehatan kepada warga, namun saat ini kegiatan tersebut sudah tidak pernah dilakukan.

Sedangkan untuk air bersih, Pemkab Sidoarjo mengirim air 10 hari sekali yang ditampung pada tandon. Bantuan air tersebut tidak bisa mencukupi kebutuhan warga karena begitu air datang, langsung habis terdistribusi. Akibatnya warga harus membeli air bersih di penjual air keliling, yang dijual di dalam jerigen dengan harga Rp 1.500/ jerigen. Air hasil pembelian tersebut digunakan oleh warga untuk minum sedangkan untuk MCK masih manggunakan air sumur walaupun kalau untuk mandi kadangkadang tubuh menjadi gatal. Bahkan pada beberapa sumur warga sudah tidak bisa digunakan sama sekali karena tercampur rembesan air lumpur. Meskipun terdapat sungai (seperti misalnya di Desa Pamotan) tetapi kondisinya sudah tercemar karena terkena air lumpur. Pencemaran air sungai tersebut mengakibatkan sumur warga jadi tercemar terutama warga yang rumahnya dekat dengan sungai Di lain sisi, sungai tersebut juga digunakan untuk mengaliri pertanian, hal ini akhirnya juga mengakibatkan kerusakan sawah karena dialiri oleh air yang sebenarnya sudah tercemar.

\section{b.2) Keeratan hubungan antar warga dan konflik sosial}

Sebelum terjadi kejadian luapan lumpur ini, hubungan antar warga di seluruh desa di sekitar tanggul ini sangat baik. Masyarakat hidup berdampingan dengan tentram dan damai. Kerukunan masyarakat sangat tinggi, kegiatan masyarakat baik kegiatan keagamaan, sosial dan peringatan hari besar nasional berjalan baik dan meriah. Tidak pernah terjadi konflik besar antar warga. Hal-hal demikian ini menunjukkan bahwa kondisi desa pada waktu itu sangat kondusif, aman dan stabil. Selain itu, jalan desa sepi karena tidak dijadikan jalan alternatif.

Namun semua berubah setelah terjadi luapan lumpur di sekitar desa mereka. Perasaan terancam dan tidak aman menghinggapi hampir seluruh warga. Seperti telah dipaparkan sebelumnya, keresahan baik secara ekonomi, kesehatan, kehidupan sehari bahkan kekhawatiran kehilangan harta benda mengakibatkan warga menjadi lebih sensitif. Berdasarkan hasil survey, hubungan antar masyarakat di Desa Mindi dan Ketapang menjadi agak renggang akibat terjadi perselisihan antar warga. Hal ini juga terjadi karena interaksi sosial yang agak menurun, diakibatkan karena beberapa warga sudah ada yang pindah rumah, atau karena kesibukan pekerjaan yang membuat mereka memang harus bekerja lebih keras dari sebelumnya. Sebenarnya perselisihan antar warga terjadi di semua desa di sekitar tanggul, khususnya yang berkaitan mengenai kejelasan nasib dan kekhawatiran warga. Meski demikian, perasaan senasib sepenanggungan membuat mereka mengedapankan kekeluargaan untuk menyelesaikan masalah. Ketakutan, kecemasan dan rasa putus asa dirasakan oleh sebagian besar warga, yang membuat perasaan menjadi lebih sensitif, yang akhirnya 
berimbas pada hubungan sosial di masyarakat.

\section{b.3) Keamanan Lingkungan}

Keeratan hubungan antar warga yang sangat bagus sebelum kejadian lumpur juga didukung oleh keamanan lingkungan yang cukup tinggi, sebesar 94,9\% responden menyatakan bahwa desanya dahulu adalah desa yang sangat aman. Namun setelah kejadian luapan lumpur, keadaan tersebut juga mengalami penurunan. Hanya $51,6 \%$ responden yang tidak merasakan perubahan keamanan dari sebelum dan sesudah kejadian lumpur. Kecemasan yang cukup tinggi akibat luapan lumpur ini mengakibatkan menurunnya rasa aman bagi warga. Karena bagaimanapun dampak dari luapan lumpur ini menyentuh seluruh aspek kehidupan masyarakat. Kejadian kriminal/ tindak kejahatan juga meningkat, terutama di Desa Penatarsewu, Sentul, Ketapang, Besuki, dan Kalitengah. Hal ini terjadi seiring dengan meningkatnya jumlah orang tak dikenal yang masuk ke desa-desa di sekitar tanggul. Sedangkan untuk wilayah desa yang dijadikan sebagai jalan alternative, seperti misalnya di Desa Kalitengah, telah beberapa kali terjadi kecelakaan lalu lintas.

\section{b.4) Timbulnya lembaga informal baru}

Dengan adanya kasus semburan lumpur di beberapa desa bermunculan organisasi baru di masyarakat yang sengaja dibentuk untuk membahas kejadian lumpur terkait dengan persoalan-persoalan sosial. Lembagalembaga tersebut pada umumnya dibentuk oleh sekelompok warga namun atas sepengetahuan pemerintah desa, yang dimaksudkan untuk menampung aspirasi masyarakat terutama yang terkait dengan kejelasan status desa mereka dan persoalan ganti rugi. Beberapa nama yang digunakan lembaga-lembaga baru sama di masingmasing desa, namun sebenarnya kelompok yang berbeda. Diantaranya adalah Tim 7 di Desa Besuki; Tim 9 di Desa Gempolsari, Ketapang dan Pamotan; Forkom Lumpur di Desa Mindi; Tim 12 di Desa Ketapang; Tim
Gabungan Korban Lumpur di Gempolsari, Kalitengah, Kalisampurno, Ketapang dan Sentul.

Namun dari berbagai lembaga informal tersebut, yang eksistensinya paling terlihat karena sangat aktif adalah Lembaga Forkom di Mindi. Melalui lembaga ini warga menyampaikan aspirasinya dan berharap kejelasan status karena warga menyatakan bahwa Desa Mindi sudah tidak layak untuk dihuni. Warga benarbenar merasakan ketidaknyamanan di tempat tinggal yang ada saat ini, namun untuk pindah juga tidak semudah karena ada banyak hal yang harus dipertimbangkan. Forkom di Mindi ini juga dimanfaatkan sebagian warga dari Desa Glagaharum untuk menyampaikan aspirasinya. Meskipun lembaga yang lain bisa dikatakan tingkat keaktifannya rendah, bahkan beberapa lembaga sudah tidak aktif lagi, namun orangorang yang dahulu terlibat masih menjadi tim bayangan di desa untuk menampung aspirasi warga.

\section{Analisa Kualitas Air dan Tanah Adanya Lumpur Lapindo}

Analisa ini dilakukan di dua Kecamatan yaitu Kecamatan Sidoarjo Kota dan Kecamatan Sedati. Dua Kecamatan tersebut terdiri dari 6 (enam) titik lokasi yang merupakan area pesisir yang memiliki potensi perikanan tambak yaitu posisi I.I dan posisi I.II lokasi di pulau Lusi (Jabon), posisi II.I dan posisi II.II lokasi di desa Bluru Kidul, posisi III.I dan posisi III.II lokasi di desa Kalanganyar Kecamatan Sedati. Hasil analisa tersebut menunjukkan bahwa:

f. Dampak terjadinya semburan lumpur atau dikenal dengan Lumpur Lapindo berubah nama menjadi Lumpur Sidoarjo (Lusi), menunjukan tidak memiliki dampak negatif terhadap usaha pembudidayaan ikan dikawasan pesisir kabupaten Sidoarjo. Hal ini terbukti dengan data Time Series produksi budidaya ikan di tambak data tahun $2006 \mathrm{~s} / \mathrm{d} 2010$.

g. Untuk jenis ikan bandeng sebagai komoditas unggulan terbesar (42\%) dari total produksi JATIM yang digemari konsumen menunjukkan trend yang konstan sejak 2006 s/d 2008. Selanjutnya dari tahun 2009 s/d 2010 
mengalami kenaikan, artinya bahwa dengan adanya bencana semburan lumpur lapindo tidak mempengaruhi kualitas air jadi menurun yang berakibat pada menurunnya jumlah produksi pertambakan. Sedangkan udang windu dan udang vanname mengalami kenaikkan pada tahun 2009 s/d 2010 sebagai komoditas export sesuai dengan barchart yang dapat diperlihatkan pada Gambar 1.

h. Dari hasil analisa untuk air 12 parameter dan 4 parameter untuk tanah kesemuannya menunjukan hasil analisa pada kisaran normal kecuali pada titik I.I tekstur pasir 87,82 \% dinominasi oleh pasir yang tinggi, hal ini tidak menjadi masalah untuk perikanan lorong karena tekstur liat dan lempung cukup tersedia, sehingga tidak terjadi gejala porus (bocor) bagi kostruksi kanal bila dijadikan perikanan lorong maupun kolam tambak air permukaan akan dapat bertahan

i. Kawasan desa Bluru Kidul kecamatan Sidoarjo Kota parameter tanah untuk bahan organik cukup tinggi sebesar $11,895 \%$ dan lempungnya $53,7 \%$, hal ini dikarenakan kondisi tambak yang sudah lama (tua) dan kurang dilakukan reklamasi dasar tambak, namun tidak menjadi masalah jika dikembangkan menjadi tambak udang teknologi intensif dengan reklamasi untuk pembudidayaan udang dan bandeng

j. Kawasan di desa Kalanganyar Kecamatan Sedati untuk pengembangan pembudidayaan ikan cukup potensial dan tidak ada inidikasi masalah unsur bio-fisik terutama parameter air dan tanah terhadap media budidaya ikan layak untuk diusahakan dan dikembangkan

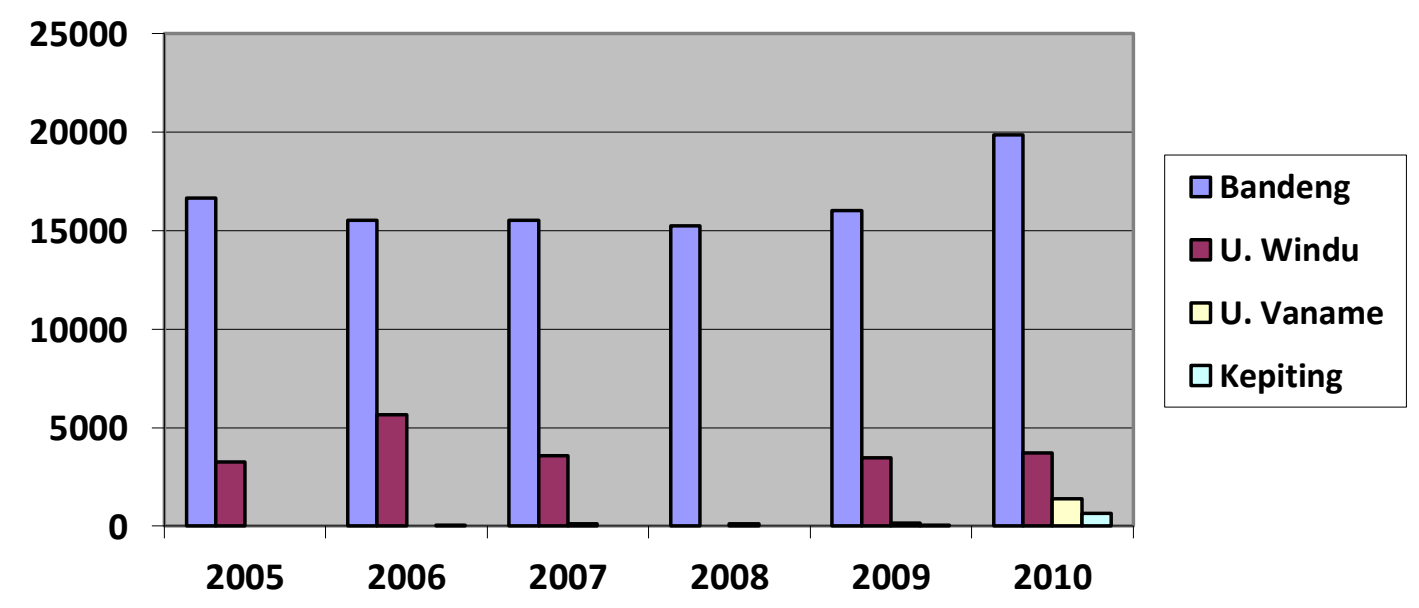

Gambar 1. Produksi Budi Daya Tambak Menurut Jenis Ikan Sebelum dan Sesudah Kasus Lumpur Sidoarjo Tahun 2006 (Ton)

\section{KESIMPULAN}

Berdasarkan hasil analisa dan pembahasan yang telah dipaparkan sebelumnya, maka simpulan yang diperoleh dari penelitian ini adalah:

1. Hasil analisa sosial ekonomi adanya bencana lumpur lapindo menunjukkan pengaruh yang signifikan terhadap kondisi sosial secara psikologis dan kondisi ekonomi secara umum. Secara sosial dan ekonomi, saat ini pemerintah dan pihak perusahaan sudah memberikan solusi dalam hal ini adalah ganti rugi. Namun kebijakan tersebut masih bersifat sepihak artinya antar korban masih terjadi ketimpangan atas biaya ganti rugi yang diberikan oleh pemerintah dan pihak perusahaan, sehingga masih sering terjadi demonstrasi diantara korban atas ketimpangan tersebut.

2. Hasil analisa kualitas lingkungan dengan uji laboratorium kualitas air dan tanah menunjukkan bahwa adanya bencana lumpur lapindo tidak berpengaruh secara signifikan terhadap kegiatan perikanan tambak, hal ini ditunjukkan dengan hasil produksi perikanan tambak dari tahun 2006 sampai 2010 mengalami kenaikan.

3. Hasil analisa baik secara sosial, ekonomi dan ekologi (uji kualitas air dan tanah) yang telah dijelaskan minimal 
harus dapat dipertahankan dan guna mencapai terwujudnya pembangunan berkelanjutan, maka kondisi sosial, ekonomi dan ekologi harus berjalan secara seimbang.

\section{SARAN}

Berdasarkan kesimpulan di atas, maka rekomendasi yang diusulkan dari hasil penelitian ini adalah:

1. Pemerintah dan pihak perusahaan harus segera menyelesaikan ganti rugi kepada korban, sehingga demonstrasi dari korban tidak terjadi lagi.

2. Pemerintah daerah dalam hal ini adalah Kabupaten Sidoarjo, harus memiliki kebijakan yang tepat dan cepat dalam rangka mempertahankan dan meningkatkan kualitas lingkungan pesisir dengan membuat kebijakan baru untuk pengembangan budidaya perikanan tambak, baik kebijakan dalam aplikasi minapolitan maupun lainnya.

3. Dalam rangka mewujudkan tercapainya pembangunan berkelanjutan, maka hasil penelitian ini minimal dipertahankan kondisinya, dan pemerintah Kabupaten Sidoarjo harus membuat kebijakan yang lebih aplikatif untuk kawasan pesisir, seperti minapolitan dan gemopolis.

\section{DAFTAR PUSTAKA}

Bowen, R, Riley, C (2003) Socio-economic indicators and integrated coastal management. Journal Ocean \& Coastal Management 46, 299-312

Baun, P. S (2008) Kajian Pengembangan Pemanfaatan Ruang Terbangun Di Kawasan Pesisr

Kota Kupan. Tesis

Direktorat Jenderal Pembangunan Daerah (1998) Penyusunan Kebijakan Pengelolaan

Wilayah Pesisir. Laporan Akhir. Bogor.

Fedra, K and Feoli, E (1998) GIS technology and spatial analysis in coastal zone management. Published in: EEZ Technology, Ed. 3, pp171-179

Kemp, R., Parto, S. and Gibson, R.B. (2005) Governance for sustainable development: moving from theory to practice. , International Journal Sustainable Development, Vol. 8. pp. 12-30

Schroeder, A (2002) Rio to Jo'burg and Beyond The World Summit on Sustainable Development. The South African Institute of International Affairs.ISBN: 1-919810-52-8. SAllA Report No. 25

Kabupaten Sidoarjo Dalam Angka (2010). Badan Pusat Statistik Kabupaten Sidoarjo

Kusnadi, M.A., (2003) Akar Kemiskinan Nelayan. LKiS Yogyakarta

Profil Kabupaten Sidoarjo (2010). Laporan

Sarda, R, Avila, C and Mora, J (2005) A methodological approach to be used in integrated coastal zone management processes: the case of the Catalan Coast (Catalonia, Spain). Journal Estuarine, Coastal and Shelf Science 62, 427-439

Supriharyono (2007) Konservasi Ekosistem Sumberdaya Hayati di Wilayah Pesisir dan Laut Tropis. Pustaka Pelajar. Yogyakarta.

Soetomo dan Sugiono (2005) Sistem Pembangunan Hunian Masyarakat di Wilayah Pesisir. Workshop dan Pelatihan pembangunan Wilayah Pesisir berkelanjutan di kabupaten Aceh besar.

Syarief. E (2001) Pembangunan Kelautan Dalam Konteks Pemberdayaan Masyarakat Pesisir. Majalah PP Edisi-25

Sugiyono, R. 2008. Statistik a untuk Penelitian. Bandung: CV. Alfabeta.

UU Republik Indonesia No. 26 Tahun 2007 Tentang Penataan Ruang

UU Republik Indonesia No. 27 Tahun 2007 Tentang Pengelolaan Wilayah Pesisirdan Pulau-Pulau Kecil 